\title{
Identification and Validation of ESP Teacher Competencies: A Research Design
}

\author{
G. Venkatraman ${ }^{1} \&$ P. Prema ${ }^{2}$ \\ ${ }^{1}$ School of Humanities and Sciences, SASTRA University, India \\ ${ }^{2}$ Formerly Dean, Faculty of Education, Alagappa University, India \\ Correspondence: G. Venkatraman, Associate Professor of English, School of Humanities and Sciences, SASTRA \\ University, Thanjavur-613402, Tamil Nadu State, India. Tel: 91-999-471-7366. E-mail: gvr.eng@gmail.com
}

Received: November 15, 2012 Accepted: December 6, 2012 Online Published: December 26, 2012

doi:10.5539/elt.v6n2p27 URL: http://dx.doi.org/10.5539/elt.v6n2p27

\begin{abstract}
The paper presents the research design used for identifying and validating a set of competencies required of ESP (English for Specific Purposes) teachers. The identification of the competencies and the three-stage validation process are also discussed. The observation of classes of ESP teachers for field-testing the validated competencies and evolving of the competency scale for ESP teachers are also presented. The research design and the methodology followed are given hoping that this will serve as a model for future research on teacher competency.
\end{abstract}

Keywords: ESP teacher competencies, identification and validation, research design

\section{Introduction}

'Teacher competency' is a prominent research area world over. Identifying a set of required competencies for teachers of various levels and disciplines is being done in developed countries by state funded committees of experts and is validated by using some established methods/techniques. Later the competencies are adopted by the states for teacher certification and training. The first author of the paper, for his Ph.D. programme titled "Developing a Set of Competencies for Teachers of English in Engineering Colleges," identified and validated a set of 65 competencies for teachers of English in engineering colleges. The research design followed for the study is presented in this paper.

\section{Related Studies}

Paz (1980) made a study on bilingual education Spanish/English teacher competencies. The study identified the competencies necessary for an effective teacher in a bilingual/bicultural program using Spanish and English as mediums of instruction. Bilingual education teachers, bilingual education project directors, and educators involved directly in teacher training in bilingual education, determined the needed competencies. The study generated lists of specific competencies for bilingual education teachers.

A project undertaken by Barrett et al. (1997), titled "A Competency Framework for Effective Teaching", which was funded by Murdock University, Western Australia, articulates a set of teaching competencies for university teaching. The competencies have been developed from literature based on research into the effect of university teaching on student learning and through consultation with the Murdock academic community. Thirty-two competencies for effective teaching were developed by the project, which were grouped under nine strands. The first five strands are core-teaching competencies and remaining four are teacher leadership competency strands.

Haddock (1998), Project Officer, TESOLANZ Professional Standards Project, New Zealand, talks about the parameters of the ESOL project, and the core competencies developed by the project. The project initially investigated such competencies related to the kinds of appropriate knowledge, skills, attitudes and experience required for ESOL Teaching contexts and selected the key indicators of competence within the TESOL profession. Finally a set of 36 competencies in four categories - knowledge, skills, attitudes, education and experience was developed.

Norizan and Embi (2003) of University Kebangsaan Malaysia (UKM) in their article "A framework of Information Technology (IT) competency for English language teachers in Malaysian schools," present a 
framework of IT competency for English language teachers in Malaysian schools. They recommend that the framework be referred to in preparing the new entrants to the teaching profession and as a guideline for professional development for the English language teachers in Malaysia. The study identified the IT competencies that are important for the English language teachers in Malaysia. The identification of the competencies was done via document analysis, exploratory interview and from literature review. The identified competencies were collated and face validated by two educational experts and further validated for its content in a three round Delphi procedure with a panel of 15 experts. The 98 competencies identified are classified into eight categories.

These studies give an overview of how identification and validation of teacher competencies are done in some countries, from which readers develop a comparative perspective.

\section{Method of the Study}

The present study is exploratory by nature and survey technique and content analysis were adopted. The study followed both quantitative and qualitative research approaches.

\subsection{Population of the Study}

The population of the study undertaken by the author titled "Developing a Set of Competencies for Teachers of English in Engineering Colleges," is all the teachers of English working in the 230 Engineering Colleges (when the study was carried out between 2003-06, now the number is more) in the State of Tamil Nadu, India.

\subsection{Sample for the Study}

150 practising English language teachers from 83 Engineering Colleges spread over the State of Tamil Nadu was taken up as a sample for the study.

\subsection{Tools for the Study}

The researcher constructed the following six research tools for the study:

i. Needs Analysis Interview Schedule for Teachers

ii. Needs Analysis Questionnaire for Students

iii. Faculty Questionnaire for Pilot Study

iv. Interview Guide for ELT/EST Experts

v. Revised Faculty Questionnaire

vi. Class Observation Schedule to Assess the Function of the Competencies

All the six tools are constructed by the researcher specially for this study and each one was subjected to face validation by two experts each. Out of the six tools developed the major tool is the Faculty questionnaire which was used to validate the identified competencies. That questionnaire was pilot tested with the help of 20 practicing ESP teachers.

\section{Research Design}

The study was conducted in three phases. The first phase was the identification of the competencies for the teachers of English in Engineering Colleges. In this phase a content analysis of available literature was made. Analysis of the Anna University (Chennai) English Syllabus and the English Text books prescribed for the B.E./B.Tech. courses were also made. A Needs Analysis Interview with English Teachers of Engineering Colleges and a Needs Analysis Survey on the Students of Engineering Courses were also made. Based on all these measures, a set of competencies for teachers of English in Engineering Institutions was identified.

Phase two was validation of the competencies identified. In the initial validation process, as the first step, the identified set of competencies was validated by five English Language Teaching (ELT) / English for Science and Technology (EST) experts. Then, in order to field validate the competencies, a pilot study questionnaire was constructed, and responses from 20 practicing English teachers were received. Based on the responses, a few of the identified competencies were dropped/added/modified.

In phase three, the final validation of the competencies was done. The set of competencies was modified after the initial validation and was subjected to expert validation. Six other ELT/EST experts gave their opinion on the competencies. After that, for field validation of the competencies, the final faculty questionnaire was prepared. Opinions from 150 English teachers of Engineering Colleges were received with the help of the questionnaire. The responses were collated and statistical analyses were made. Thus, after the final validation, a final list of competencies was arrived at. 


\subsection{Class Observation to Assess the Function of Competencies}

As the last step in the validation process, that is from the stage of identification to development of the set of competencies into a functional one, it was decided to field test the same by observing the classroom teaching of the English language teachers of Engineering Colleges. For the purpose of the class observation, 30 competencies were selected from the final list, which are observable in the real classroom situation (Though all the 65 competencies in the list are necessary, the teachers have no chance to display some competencies in the classroom. For example, the competencies like developing curriculum, syllabus design, material production, needs analysis etc., cannot be observed in the classroom teaching). Based on the list, a Class Observation Schedule was constructed in order to use it as a tool for observing the class. Ongoing classroom teaching of 20 English teachers of engineering colleges was observed and it was found that the 30 competencies were observable in one class or the other.

\subsection{Development and Validation of Competency Scale}

Based on the inputs gained from the class observation, the 'Venkatraman and Prema's Competency Scale' for teachers of English in engineering colleges was developed. As the scale has been tested in the classroom observation of the ongoing teaching of English teachers, it becomes a validated tool for assessing the competencies of the teachers of English in engineering colleges.

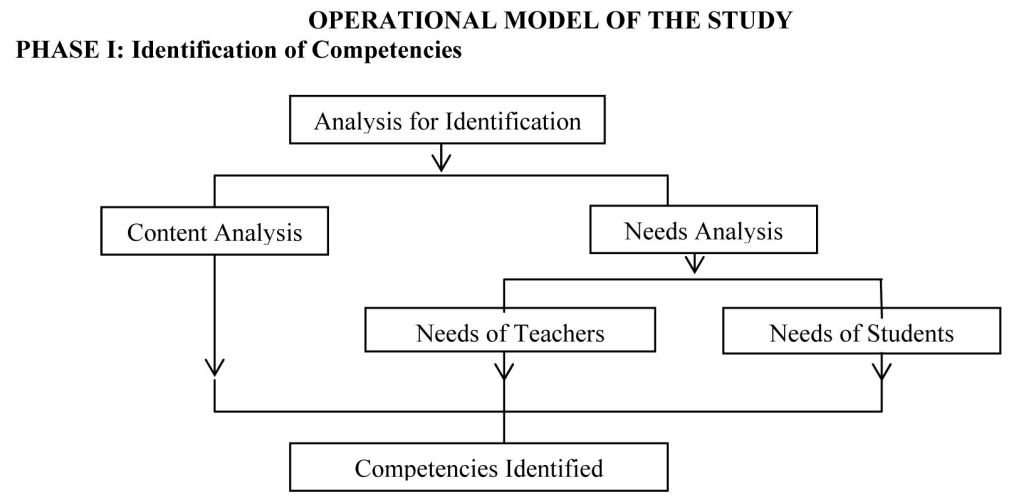

PHASE-II: Initial Validation of Competencies Identified

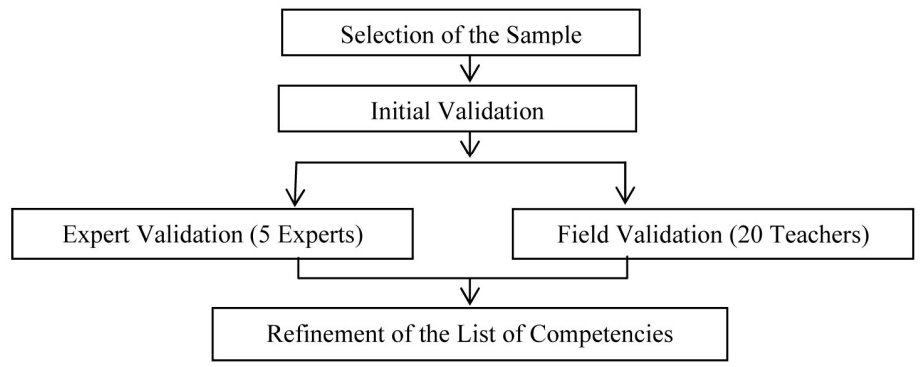

PHASE-III: Final Validation of Competencies Identified

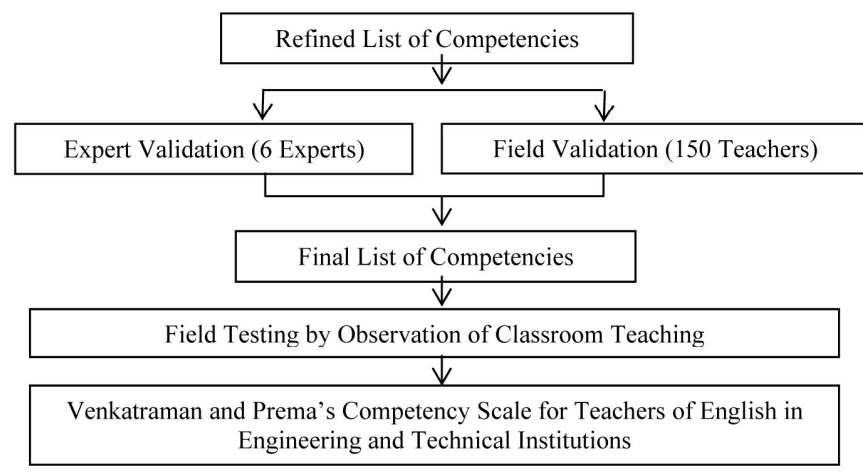

Figure 1. Operational Model of the Study 
The research design followed for the study is diagrammatically represented in Figure 1.

\section{Major Findings of the Study}

The 65 competencies for teachers of English in Engineering Colleges, which are identified, validated by experts and field tested by the researcher, form part of the major findings of the study. The 65 competencies are grouped under two parts. Part I, 'General Competencies' comprising 17 competency statements and Part II, 'Subject-Specific Competencies' contains the remaining 48 competencies which are grouped under seven domains. A descriptive statement given for each domain, states the purpose, need and the scope of the competency statements of each domain. The list of validated competencies can be viewed from the authors' paper in ESP World Journal: http://www.esp-world.info/Issue 1(14), Volume 6, 2007.

\section{Recommendations}

In the research report seven recommendations were suggested. Developing a curriculum for in-service teacher training, based on the set of competencies developed in the study; pre-service training programme for the teachers of English appointed in engineering colleges; Refresher Courses, Summer/Winter Schools, short term training programmes for training the EST teachers exclusively based on the special set of competencies developed in the study are some of the recommendations made to the All India Council of Technical Education and other Technical Universities in India.

The present paper focuses only the research design and methodology followed by the study. As the methodology proves to be effective for identifying teacher competencies for a specific purpose, it is recommended as a proven research methodology to identify and validate competencies of teachers of other disciplines.

\section{Conclusion}

The research design followed and the methodology adopted to identify and validate the set of competencies for ESP teachers are presented in this paper, hoping that similar methodology can be followed to identify the competencies of teachers of other fields. According to Fletcher (2005), you cannot use a competence-based system for any purpose until you have developed the competence measures. However, once you have the measures developed, they can be used for a whole range of assessment purposes. Devising a suitable research design and methodology to suit the particular need is suggested for developing a set of competencies of teachers of other disciplines.

This paper would be inspiring and useful for novice researchers who want to conduct research on similar issues.

\section{References}

Barrett, Jill. et al. (1997). A competency framework for effective teaching, Murdock University, Western Australia.<annieyeo@central.murdoch.edu.au>

Best, W. John, \& James, V. Kahn. (2000). Research in Education. New Delhi: Prentice Hall of India Pvt. Ltd.

Fletcher, Shirley. (2005). Competence - Based Assessment Techniques in Training. New Delhi: Crest Publishing House.

Haddock, Daniel. (2006). TESOLANZ Professional Standards Project: Core Competency Profile. Retrieved from www.tesolanz.org.nz/site/publications/reports/competency.aspx

Norizan, Abdul Raak, \& Mohamed Amin Embi. (2003). IT Competency for English Language Teachers in Malaysian Schools. Retrieved from http://www/eltrec.ukm.my/iJeLLT

Paz, Estanislado Ybarra. (1980). Identification of Bilingual Education Spanish/English Teacher Competencies, Ph.D. Thesis. The University of Arizona. p. 119. Retrieved from http://proquest.umi.com/pqdweb=752717071

Sabina, Stephen Hassana. (1984). An identification of Teacher competencies and elements of a Training program for secondary school composition Teaching in Nigeria (ESL) Education Dissertation. University of Maryland College Park. p. 187. Retrieved from http://proquest.umi.com/pqdweb748614471

Venkatraman, G., \& P. Prema. (2007). Developing a Set of Competencies for Teachers of English in Engineering Colleges. English for Specific Purposes World Journal, 1(14), 6. Retrieved from http://www.esp-world.info 


\section{Authors}

Dr. G. Venkatraman is currently working as an Associate Professor of English at SASTRA University, Tamil $\mathrm{Nadu}$, India. He has got 25 years of teaching experience especially in teaching English to students of science and technology. He earned his Ph.D. from SASTRA University, for the title "Developing a set of competencies for teachers of English in engineering colleges." He got 5 journal publications and 22 conference presentations to his credit.

Dr. P. Prema was a Professor of Education and Dean, Faculty of Education, Alagappa University, Tamil Nadu, India. She has got more than 30 years of teaching and research experience and produced $15 \mathrm{Ph} . \mathrm{Ds}$. She is an expert in educational research methodology and authored 4 books. 